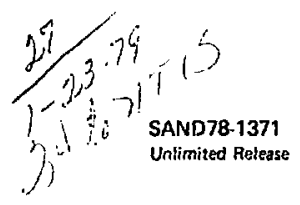

\title{
Survey of Microbial Degradation of Asphalts With Notes on Relationship to Nuclear Waste Management
}

Claude E. ZoBell, Martin A. Molecke

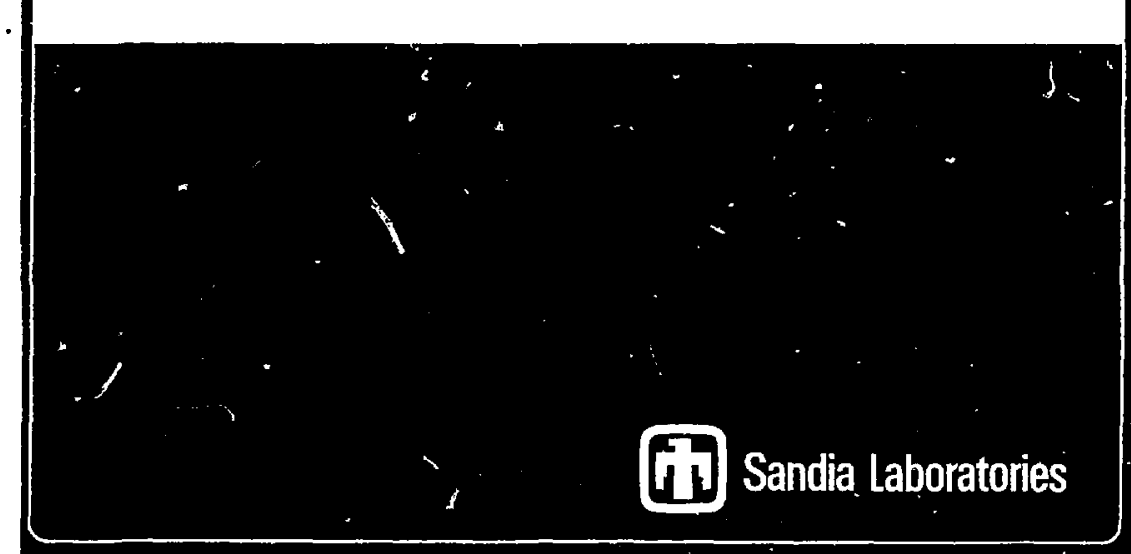

F $79000(7.73)$ 


\section{NOTICE TO RECIPIENTS}

To get Voiume I of this document into your hands as soon as possible, it was necessary to delay the printing of Volume II (which contains 958 pages). Volume II will be delivered to you as soun as it can be printed.

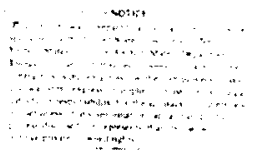


SAND78-1371

Unlimited Release

Printed December, 1970

Subnt tted July, 1978

SUAVEY OF MICHOBIAL DEGRADATION OF ASPRALTS WITH WOTES ON RELATIONSHIP TO NUCLEAR WASTE MANAGEAENT:

Claude E. zoBel1 (I) and Martin A. Molecke (2)

\begin{abstract}
A survey has been made of the microblal degradation of asphalts. Topics covered include chemical and phroical properties of asphalts, their chemical stability, methods of denonstrating their microbial degradation, and environmental extremes for microbial activity based on existing literature. Specific concerns for the use of asphalt in nuciear waste managenent, plus potential effects and consequences thereof are discussed.
\end{abstract}

(1) Scripps Institution of Oceanography, University of California, San Diego, La Jolla, California, 92093.

(2) Sandia Laboratories, Nuclear waste Experimental prograns, Division 4512, Albuquexque, New Merico 87185.

-This work supported by the U. S. Department of Energy.

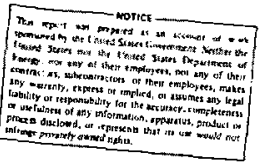




\section{IrImODUCIION}

One purpose of this report is to gumarize and document the present knowledge on the composition of asphalta and their susceptiblity to nit zobial attack under varlous environmental conditions. Although the literature on this subject is rather neager, it seems that yitually all kinds of asphalt are biodegradable by bacterla and fungl at rateg varying frou extremely slow to Ealriy rapid. The rates of biodegradation are influenced by the contact of microbial enzyme systens with the asphalt, the chenical composition of the asphalt, its physical state, and environtiental conditions.

Asphalt has been used for thousands of years to caulk boats, to cement various building materia!s, for waterproofing, and for other purposes. Large natural deposits occur in many parts of the world. Suct. deposits are known variously as bitumen, pitch, asphaltite, gilsonite, grahamite, albertite, wurtzlite, etc. Most, but not all crude oils, contain some asphalt in arounts up to 50 gercent or more. Presently in the United states, nearly all comperical asphalt is derfved fron crude oll. Nearly 75 percent of the asphalt 16 ussd for paving, about 15 percent for roofing, and the renainder for a great variety of other purposes, including waterproofing, lining water canals and reservoirs, plpe-coating, insulating, and atcmoblle undercoating. Within the last 10-15 year5, primarily in Europe, asphalt has also been used For the encapsulation of low and intermediate-level radioactive wastes (1).

The second purpose of this report is to examine the consequences of microbial degradation of asphalt used to encapsulate radioactive wastes on long-term nuclear waste management. The first asphalt (bitumen) solidification system Eor radioactive wastes began operation in 1965 at the Comisarlate a l'Bnergie Atomique (CEA) facility in Marcoule, France. 
Latge-acale asphalt colldificetion ayotens have loo been put into operation at the Rarlaruhe Nuclear Reseacch center in the Federal Republic of Gerany and at the Eurochemic Company in Nol, Belgiun. Data and lltarature pertaining ditectly to microbial attack of asphalt encopsulated rsdiosctive wate are easentially ron-existent. Coresponding research on this topic has not been performed with the same intenaty as has related work on lesching, radiolyals, and thermi 1 degradation of asphalt $\{1,2,3,4\}$.

In this paper, microblal degradation of agphalt used to encapsulate radladctive wastes will be exansned primarlly from the viewprint of terminal Isolation. This includes deep geologic fsolation in a salt wine, e.g., the Waste Isolation Pilot Plant project $(5,6)$ planned in New Mexico, in hardmock repositories, potentially in deep seambed disposal, etc. Waste lsolation in near-surface trenches (prinar $11 y$ low-level, non-tzansuranic wastea) la not emphasized; much of the general ricrobial degradation information presented herein may, however, be applicable for this mode.

Processing temperatures in the range of $80-1950 \mathrm{C}$ are used for $z$ ' asphalt encapaulation of radioactive wastes (3)-migh enough to k1ll most bacteria and fungi contained in the waste 1tbeif. However, bacterial degradation of the asphalt waste from external oources is still quite possible. Aaphalt-encapsulated wates may becone contaminated prior to bur 1 al in a terminal waste repositosy or may eventualiy becone contaninated by bacteria contained in other (organic, unprocessed) wastes which may also be buried in the repository. It should also be asgured that any $k$ ind of microorganigm may find its way into the repository during excavation and emplacement operations, some fraction of these microorganisus may survive and then adapt to the extsting environnent, potentialiy reauleing in microbial waste degradation. 
POARAYTIAC AREAS OF CONCERN

The extent and consequences of bacterlal degradation must be rank ordered against other potential problen areas for the utilization of asphalt in long-tern nuclear waste managenent. Theae other areas of concern include:

1. Fire in the course of processing, transport, or storage of the radioactive waste form. The possibility that the active asphalt-waste peoduct may burn has alwaya been considered os one of the main disadvantages of asphalt encapsulation. This is the predorainant reason that sone people prefer other waste treatment techniques (1).

2. Radiolytic degradation of aphalt yielding significant quantities of gas, prinarily $\mathrm{a}_{2}$. Internal 1 rradiation from alpha-emitting transuranic waste is expected to yield grearer gas generation than beta ard gama icradiation fron the fission and activation products incorporated in low-level wastes, Very few data exist on radiolytic gas generation from asphalt, except from beta and gamma irradiation.

3. Thermal degradation of the asphalt resulting in sweling.

1. Leaching of the active asphalt-waste matrix by ground water or brines in deep geologic isolation. The extent of this concern has been well studied $(1,2,3,4)$ and deternined not to be of overiding short-term significance. Potential enchanced migration of radionuclides (due to bacterlally produced chelating agents) following leaching has not yet been adequately addressed.

5. Hatrix solubilization (7). Many alctoorganigms have the ability to produce alcohols, esters, ketones, and other fermentation products in which asphalts are soluble, albelt only olightly. Such solubilization way be of negligible significance during a period of 
several years, but could result in the petforation or partial natcix solubilization of asphalt encapuliants or conting within cecidso or centuries. In an environnent where water and organic matter (cellulosics; protelns, l1fida, etc.m-as in unprocessed wastes) are present, along with elements esgential for microblel growth, scme solubilization of asphalt by fermentation products can be expected.

6. Petroleum product utillation. Use of large quantities of appalt for waste management may conflict with other uges or needs for this product and its derivatives. Since asphalt la not in short supply, nowever, such utilization is not expected to be of major lmpact.

Further study is necessary before the relative degree of concern for bacter dal degradation of asphalt can be adequately evaluated in relationship to its nutleat waste managenent use. The possiblity exists that none of the stated concerns will be judged (via a cost-risk-benefit analysis) suffickent to hinder the utilization of asphalt for cadioactive waste encapsulation.

\section{CHEMICAL PROPERTIES OF ASPAALTS}

Asphalts are conglomerates of high molecular-welght hydrocarbons, resins, and asphaltenes, mixed sometimes with up to 27 percent by weight of minerals. After being heated to $100^{\circ} \mathrm{C}$ to expel water and gases, the mineral content of certain asphalts may be as high as 36 percent. There are many $k$ inds of asphalts, differing widely in chemical composition, depending on sources and treatments.

All asphalts are black or dack brown in color, Insoluble in water, and generally solid at temperatures below $70^{\circ} \mathrm{C}$. They consist mainly of carbon, nydrngen, sulfur, and oxygen (B). The elenentary composition of asphalts free of minerals, water, and gases is as follows: 


$\begin{array}{lr}\text { Carbon } & 80-86 \\ \text { Hydrogen } & 9-11 \\ \text { Oxygen } & 1-17 \\ \text { Sulfur } & 1-9 \\ \text { Hitrogen } & 1 \\ \text { Aeh } & 0.1-1\end{array}$

These elements occur in four major components: aaturated hydrocarbons, resing, eyclle hydrocarbons, and asphaltenea in varlous proportions.

According to sachanen (9), asphaltenes are dispersed colloidally in petcoletu due to peptonization by absorbed resins and heavy polycyrilc hydrocarbons, whereas regins form true solutions in petroleum. Asphalts derlved by refining petroleum generally have more paraffinic side-chains than natural asphalts such as ghlsontte at abertite, for example.

Asphaltenes, which make up $f r c m ~ 11$ to 32 percent of the bulk of asphalt, are insoluble in nonpolar paraffinis hydrocazbons, soluble in carbon aisulfide and chloraform, only slightly soluble in alcohol, ether or low molecularweight paraffinic hydrocartons, and insoluble in water. Asphaltenes contain rather high proportions of oxygen (3-11 percent) and sulfur (mostiy 7-9 percent). The components are mainly high moltcular-weight (\$ 1500) arowatic and heterocyclic hydrocacbons. The asphaltenes melt in the range of 280 to 2800C. By hydrogenation at moderate temperatures, asphaltenes may be partly converted to cesinous gaterials. Bydrogenation at high temperatures and increased pressures results in a low yield of liquid hydrocarbons. 
Rettins are amorphous solidg that are coluble in most hydrocatbon solvents, The compounds forming reains are structurally ainilar to those forming asphaltenes, Up to 22 percent, but generally lese than 10 percent, of natural asphalts conelste of resins. These are mostiy napthenic acids of high molecuiar weight (arund 600 ). Like the agphaleener, the cesine in asphalts contain rather high proportions of sulfur and oxygen.

The paraffinic, naphthente, and aromatic hydrocarbons in apphalte, along with heterocyclic compounus contalning eulfur, nitrogen, oxygen, and amall amounts of various metals, have molecular weights ranglng from 500 to sco0, although small anounte of lower molecular-weight compounds may be present. An average of 35 percent of the hydrocarbon fraction is saturated; 50 percent or more is arcmatic. Sulfur is present primarily in thlophenes and benzthlophenes, with smallex quantities in sulfoxides. Oxygen 13 present: mainly in hydroxyl, carbonyl, and ester groups. Nitrogen is present prinarily as pyridines and pyrrolemtype structures (10).

\section{PHYSICAL EROPERTIES OF ASPHALTS}

At ordinary temperatures, typical agphalts appear to be lyophilic collolds made up of asphaltenes, resins, and hydrocarbons (BC). The term lyophllic denotes a strong affinity between a collola and solute in which it 18 dispersed. The sane asphaltene dispersed in various HC-resin comblnations may yield essentially similar asphalts. Micelles of coal-tar pitches and bitumens consisting of highly cyciic, preauably polyaromatic gc's of high molecular weight, are believed to be surrounded by layers of aromatic compounda grading into naphthenic and paraffinic structures.

As the temperatuze of asphalt le increased, e.9., Eron 250 up to 400-600\%, collofdal and micelle structure is altered, volatile substances 
are lost, and the fluidity of the residue increaseg until it flows almost like lubricating oll. When cooled to $25^{\circ} \mathrm{C}$, the resulting product is usually less flukd and more prone to be belttle than it was originally. Further cooling causes progressively less fluldity or higher viscosity lfluidity is the reciprocal of viscosity].

(If asphalt encapsulated tranguranic radioative wastes are determined to be acceptable for deep geologic waste isolation, the storage temperatures to be expected in the haste Isolation Pilot Plant would range from $25^{\circ} \mathrm{C}$ to a maximum of $\left.70^{\circ} \mathrm{C}(5,6)\right)$.

The viscosity of agphalts is high, ranging from $10^{3}$ to $10^{20}$ poises at 0 ta $50^{\circ} \mathrm{C}$. Por comparison, the viscosity of water at $20^{\circ} \mathrm{C}$ is 0.01005 poises while heavy machine oll has a viscosity of 6.6 poises. The viscosity of a natural pitch is $1.3 \times 10^{10}$ poises at $15^{\circ} \mathrm{C}, 5.1 \times 10^{11}$ poises at $0^{\circ} \mathrm{C}$. At $-77^{\circ} \mathrm{C}$ (the temperature of a mixture of dry ice and ether) asphalts lose all semblance of fluidity.

The density of asphalts ranges from 1.1 to $1.5 \mathrm{~g} / \mathrm{cm}^{3}$. Host pitches have a dens'ty of sarely 1.1 as compared with 1.4 to 1.8 for anthracite coal and 0.87 to 0.91 for paraffin wax. Nearly all crude olls are lighter than water, 1.e., less than $1 \mathrm{~g} / \mathrm{cm}^{3}$.

\section{CABFYICAL STABILITY}

Aaphalts are generally reglstant to many chemical reagents. As an indication of the oxidation resistance of various components of asphalt, sunlight tends to oxidize:

aephal tenes > resins > aromatic HCs > saturated HCs 
[Sunlight, obviously, is not a concern for deep geologic isolation of radidactive wastes. Oxidation 1s.) Different types of agphalt pary greatly In thetr susceptiblitity to solaz radiation oxidation. Afr-blowing anghalt to increase its hardness increases lts cesigtance to oxidation by gunight. Air-blown asphalt is produced by blowh aff through molten osphelt at $150-250^{\circ} \mathrm{C}(10)$. During ." $\mathrm{s}-\mathrm{bl}$ lowing, oxygenation and dehydrogenation reactions take place. Nearly one-third of the asphalt produced by industry is air-blown, which converts it into plastic. Many varleties of both blown and distilled asphalts have been utilized for radioactive wasto encapsulation. The microbial oxidation of asphalts has been reported by Tauson (11), Hundeshagen (12), ZoBel1 (13), Burgess (14), Harr 1s (15), Kulman (16), Traxler et al. (17), and several others.

Asphalt resists attack by dilute sulfuric acld but is attacked by concentrated sulfurle actd and by all concentrationt of nitric actd and hydrochloric acid. It does not seem to be attacked by organic acida. Asphalt is not attacked by concentrated alkaline solutions at ordinary temperatures, although dilute alkaline solutions react wth acldic asphalt constituencs to fccis salts such as soditm naphthenates which serve as excellent emulsifying agents for asphalt.

Insufficient data exists for the longuterm (hundreds to thousands of years) chemical stability of asphalt encapsulated radioactive wastes which may be placed in a deep geologic, terminal waste lsolation repository. The chemical durability (i.e., potential leaching by ground waters or brines, interactions with waste containers and adjacent geology/ of such wastes would also be potentially compromiged by the effects of radiolytic and thermal degradation, as well as by potential microbial atcack. 
The mirrobial actifities of greatest concern for nuclear waste dispobal are those involving metal netabolino, particularly netabol.lsm of the heavy metal actinides. There are flye major types of metal transformations found in biological systems $(7,18,19)$ :

1. Complex and chelate formation of metal lons with organic ligands. organte aujds, hydroxamateg, and other microbial metabolic products are very affective chelating compounds $(19,20)$. Of primary concern is the enhanced migration of chelated actinide elements (leached from organic matrix tranguranic wastes) meving through the lithosphere (from deep geologic isolation) towards the blosphere. Heterotrophic bacter $1 \mathrm{a}$ and fungl msy also degrade metal complexing agents resulting In precipitation of the released ion as water-insoluble hydroxides, oxides, or salts $(19,21)$, thereby retarding nuclide nigration.

2. Eetabol.1sm which results in oxidation atate changes of metals, the metal participating in oxidotion reactiong "zich provide energy for microbial growth. It has been experimentally derronstrated that the oridation states of actinide elements in solution, and changes therein, have a significant effect on migration rates in the 11thosphure (22). Microorganisms have been utilized for controlled in situ bacterial leaching of uranium ore (23). Both autotrophic and heterotrophic microozganisms can produce oxidizing and reducing agents, functional in afther the solubilization or deposition of uranium (24). S1milar leaching of plutonium from transuranic wastes may be extrapolated. Bacterial metabolic action, as well as complex and chelate formation, could have a significant effect on extent of 
radionuclide (1.e, uranium and plutonfun) migration in wate repositoty.

3. Substitution of one metal for another within the vicrobe. This process often occurs wh metal cortalning snzymes. The coneequence of the substitution procesa may be to accumulate and secuester elements whin the microblal cell, renoving the clements from solution (19). As applied to nucleac waste managenent. this process ylelds two possible, opposing consequences lassining that actinide and/or fission product metals are substituted]:

a) subst 1 tuted radionucl ide aqueous phase nisration is significantly retarded due to aboorption or precipitation;

b) fisstonable radianuclides (U, pu) are bloconeentrated to a sufficient extent to result in a criticality incident. (rop likelihood of, or congeguences of, such a criticality cccurrence are not well quantified at this time.)

4. Another patent ial mechanism of bactertal bloconcentration for radionuclides is the extracellular precipitation of metals in bacterial mucilage, holdfasts, stalks, and sheaths. There are numerous bacteria which produce extracellular polymers which result in the bioconcentration of 1 ron and ranganese $(25,26)$. The cheralcal mechanism involved is presently unknown but does not necesgarily involve cell metabolism.

5. Aklylation of metals by blological systems. This is the process involved in the formation of nethyl wercury and trimethyl selenide (19). This process is not welI understood. Eron a nuclear waste managenent viewpoint, it is $\mathrm{L}_{\text {. }}$ of concern for the potential 
volatilization of organo-netal compounda of flaston products le.g., Cs, Sr, I) and actinide elements $(e .9 ., O$, Pu) found in the waste.

$\lambda$ laboratory and sield invertigation progran to quantify the $z$ ate, extent, and censequences of bacterial degradation (for the topica Iisted above) of radionucifde-contaninated organic atrix tranguranic wastes (1ncluding asphalt satr (x) on long-term nuclear waste lsolation has recently been inftiated (7,27) (bay, 1978). Th1s study is a vegment of the waste Isolation P1lot Plant (WIPE) Transuranic Wagtes Experinental Characterization Progran (6). These atudies will specifically include blogeochemical mechanians of cadonuclide mobilization and Impobilization, alcrobial prodistion of gases, and microbial transformation tates of gases that were produced abiotically, all under conditions expected in the bedded salt wIpp facility (temperature: 250-70\%C, pressures: 1-150 atmospheres, salt mine geochenistry, radiation fields or iginating from plutonium contaninated transuranic wastes, and, guite possibly, an anaeroble atnosphere in the long-tern). Also included are an assessment of naturally occurcing mickocganiams found in varlous exigting transuranic waste containets (contemporary to 30 years old) and adjacent solis at the Los Alanos Scientific Laboratory (New Nexico) waste burial sites and the effects of existing microflora under rarying conditiona of hydration, temperature, salinity, $\mathrm{pH}$, and radiation on transuranic mobility (27).

Microbial degradation data and interpretationa thereof will be utilized in overall wIPp safuty and conegguence assesment studies for dstermining the long-tern environmental safety of toolat; 9 transurante wastes in a bediedBalt, deep geologic repository. Bacterial degradation studies will also be useful In deteraining which types of organic matrix waste are safe for acceptance in the WrR; the data will help in the egtablishment of acceptance criteria relevant to biological mcdes of degradation and any resultant conseguences. 
As with sost particulate and insoluble subetances, the rate of attack by microblal enzyate systems in irectly proportional to the suiface area exposed to oxygenated water and enzysea. Being incoluble in wacer, apholts to be tested for atcroblat degradabiltty are generally opecially trated to accelerate the reaction by increasing the surface area without unduly modifying the chenical propertigs of the aphalt. Unless do treated, it might require manths or years to demordtrate appreciable anounte of micrablal degradation, Two methods with many modificationg have been employed:

1. Counks of asphalt ate cruahed or pulverized to give innuarable $t$ iny pleces. Sinse nost asphalitg are plastic at ordinary temperatures. they are more sisceptible to pulveriation at $-75^{\circ} \mathrm{C}$ or colder. The pulver 1zed aphalt is kept frozen until dispersed in nutrient medium, which usualiy contains Band, diatonaceoua earth, bentonite, etc. , to hold the asphalt particles apert.

2. Asphalt ta digsolved in the mintmal waunt of benzene or chloroform at $800 \mathrm{C}$ for mixing with inert solide such as sand, clay, crushed glass, etc. After thorough $n i x i n g$, as in a ble der, messured quantities of the mixtlice are transferred to culture flagks for autoclave ater $1132 a t i o n$ at $1210^{\circ} \mathrm{C}$, which ditues oft all of the solvent.

Modification of the solvent method includes (a) coating glass microscope sifdes with extremely thin fims of anphalt. After incubation in wineral salts medium, the slides can be examined with a microscope to determine whether bactria have grown on the asphalt or if the asphalt has been perfocated by alcroblal actiulties (enzymatic), (b) in auch the gane way, wires can be costed with thin flims of asphalt. Colls of such insulated wires 
can be incubated in minecel salts nedium (oome Inoculated with bacter la and the controls without) and teated perlodically for capacitance, conductance, and other froperties.

Several other criterta have been ugad by diEferent invegelgators to determine whether varicus asphalts have been degraded by bactarls or fungl:

1. A substantial increase in the number of microbial celis found in mineral salts medium containing aphelt as the only sourc: of energy indicates the nicrobial utilization of asphalt. Sach unit weight of alcrobial bionasg produced expressed as carbon indicates that at leest a like amount of carbon hag been extracted from the asphalt. The ratio is more $11 \mathrm{kely}$ to be $1: 2$, because in iuch energy-yielding reactions, at least half and generally more of the carbon extracted from the substrate is oxidized to $\mathrm{O}_{2}$.

2. Heosuring the amount of $\mathrm{CO}_{2}$ produced indicates the amount of asphalt carbon that has been completely oxidized.

3. Oxygen uptake is an indicator of the amount of carbon compound oxidized, assuning that the medium contains no otber oxidiable substance. As with other tests, this nust be established by the use of appropriate controls.

1. Shanges in the appearance of asphalt, its pltting in films of its disappearance provide direct evidence for degradation. The rate of microbial degradation under ordinary conditions is usually so slow that several months may be requiced to abtain definitive results. Long incubation perlods are also required before there are meaningful changes in weight or volume of asphalt, whereas microbial growth, $\mathrm{CO}_{2}$ production, or $\mathrm{O}_{2}$ uptake may indicate sone asphalt oxidation within a week or two at $25^{\circ} \mathrm{C}$. 


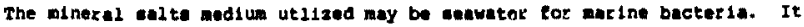
may be nearmeturatad beine if one 21 concermed with bacter 10 which woy survive and degrade wastes in a beditd snit geologic repository such as the wrPP in southeatern Hew wexico.

Composition of bzines and groundwater of apecific application to wrPE-related atudiea are liated in the following table (28).

$\underline{\text { Ion }}$

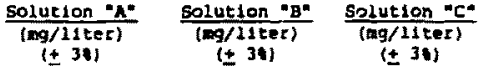

\begin{tabular}{|c|c|c|c|}
\hline $\mathrm{Na}$ & 42,000 & 115,000 & 100 \\
\hline $\mathbf{x +}$ & 30,000 & 15 & 5 \\
\hline $\mathrm{Mgt+}$ & 35,000 & 10 & 200 \\
\hline Cat+ & 600 & 900 & 600 \\
\hline Pet+t+ & 2 & 2 & $i$ \\
\hline Srt+ & 5 & 15 & 15 \\
\hline $\mathrm{Lit}$ & 26 & - & $-\infty$ \\
\hline Rat & 20 & $I$ & $\mathfrak{l}$ \\
\hline Cs* & 1 & 1 & $i$ \\
\hline C1- & 190,000 & 175,000 & 200 \\
\hline $\mathrm{SO}_{4--}$ & 3,500 & 3,500 & 1,750 \\
\hline$B\left(B O_{3}---\right)$ & 1.200 & 10 & $--\infty$ \\
\hline $\mathrm{HCO}_{3-}$ & 700 & 10 & 100 \\
\hline $\mathrm{NO}_{3}-$ & -- & -- & 20 \\
\hline $\mathrm{Br}=$ & 400 & 100 & $-\infty$ \\
\hline 1- & 20 & 10 & - \\
\hline pa (adjusted) & 6.5 & 6.5 & 7.5 \\
\hline specific gravity & 1.2 & 1.2 & 2.0 \\
\hline total aissolved sollas & $306 g / 1$ & $2979 / 2$ & $3.79 / 1$ \\
\hline
\end{tabular}

The above solutions are representative of waters which could potentially intrude into the waste Igolation Pilot Plant. Specified PH values of these salutions are representative of the "as measured" pH's of the naturally occurring solutions on which they are based.

Solucions "A and "B" are near-scturated brines. Solution "A" 15 baged on the analyaes of asveral brines from the Salado region overlying the planned 
WIPP facllity storage hor 1zon. This is a potash bearing region and conaequenty is enriched in both potasalum anc magnesium lons, relative to sodium ehloride. Solution " $A$ " is intended to be representative of brine which could intrude into the wate hortzon via tlow or percolation from above.

Solution " $B$ " is basad on the andyata of the boine obtained by dissoluing a portion of rock salt core in de-iontzed vater. The balt core vas frou the ABC 18 hole, less than four milea from the center of the planned wrpp facility. This analyzed beine has an approximstely 904 Nacl content and a total undissolved content (primarily mixed clays, not included in analysis) of less than 18. Solution "B" is representative of the brine resulting from a concelvaile catastrophlc scenar 10 at the WIPp mine (flooding, service watec line rupture, ete.) whereby water pourg in, dissolves the salt, becones gaturated, then begins to attack the wate during the operational phase of the facllity. It 18 also the brine resulting from salt being dissolved with any water released Erom the wate form itaelf.

Solution "C" is representative of groundwater pluped from one of the aquifers in the Rustler formation, baged on two epparate analyses. It consists primarily of dilute colution of calcium and magnesiur sulfates.

A general purpose medim for many soli and frest-water microblota has the following composition:

$\begin{array}{ll}\mathrm{K}_{2} \mathrm{ERO}_{4} & 1.0 \mathrm{~g} \\ \mathrm{NaCl} & 2.0 \mathrm{~g} \\ \mathrm{MgSO}_{4} . \mathrm{HB}_{2} \mathrm{O} & 1.0 \mathrm{~g} \\ \left(\mathrm{Na}_{4}\right)_{2} \mathrm{SO}_{4} & 1.0 \mathrm{~g} \\ \mathrm{CaCO}_{3} & 2.0 \mathrm{~g} \\ \text { Trace elerent solucion } & 5.0 \mathrm{ml} \text { (described below) } \\ \text { Distilled water } & 1000 \mathrm{ml}\end{array}$


The trace element solution, pcepared in $0.1 \mathrm{v} \mathrm{hCl}$, contains per $5 \mathrm{ml}$ :

$\begin{array}{ll}\mathrm{Fe} 1 \mathrm{SO}_{4} \mathrm{\gamma}_{3} \cdot 9 \mathrm{H}_{2} \mathrm{O} & 2.5 \mathrm{mg} \\ \mathrm{AnCl}_{2} \cdot 4 \mathrm{H}_{2} \mathrm{O} & 0.9 \mathrm{mg} \\ \mathrm{Co}\left(\mathrm{NO}_{3} \mathrm{~J}_{2} \cdot 6 \mathrm{H}_{2} \mathrm{O}\right. & 0.6 \mathrm{mg} \\ \mathrm{ZnSO}_{4} \cdot 7 \mathrm{H}_{2} \mathrm{O} & 0.2 \mathrm{igg} \\ \mathrm{H}_{2} \mathrm{HOO}_{4} & 0.1 \mathrm{mg} \\ \mathrm{CuSO}_{4} \cdot 5 \mathrm{H}_{2} \mathrm{O} & 5.0 \mathrm{~g}\end{array}$

The $\mathrm{pH}$ ot the medium may be adjuated to about 7.0 with dilute NaOH. Should one want to determine whether the microblal degradation of a given asphalt occurs at higher or lower ph valued, the pa of the medium should be adjusted accordingly. It is within the realm of possibility that such activity could occur at ph values as 10 as 1.0 or as nigh as 10.5 . however, most soll and aquatic bacteria, lncluding asphalt oxidizers, grow best within the range of ph 6 and 8 .

\section{RATE OF DEGRADARION}

Even under the most favorable conditions for the microbial degradation of asphalts, the rate is generally very slow. It usual $\perp_{2}$ equices several days to a few weeks to demonstrate the microblal degradation of various asphalts. The rate is influenced primarily by the chemical composition of the asphalt and particularly its phyaical site. The rate of its degradation appears to be directly proportional to the surface area exposed to oxygenated water per unit weight of asphalt. Host natural solis seem to contain enough moisture to satisfy the water requirenents of bacteria (29). Cectain olf-oxidizing 
bacterie nay contain enough water to encble then to oxidize o11, renulting in the formation of enough water to ketp than growing (30):

$$
c_{15} \mathrm{H}_{32}+23 \mathrm{o}_{2} \rightarrow 15 \mathrm{CO}_{2}+16 \mathrm{R}_{2} \mathrm{O}
$$

Determination of the minimu tnount of water necessary for microblal activity is an area that requires further atudy. The amount of water avaliable in a deep geologic waste respoltozy $4 \mathrm{~s}$ not yet well guantified, but $1 \mathrm{~g}$ expected to be extremely amall (In a bedded salt repoaltory, about 0.5 welght percent) or not avallable. This may de a signizicant limiting factor to microblal action, riftigated, of courge, by the anount of molsture avalibble in an individual waste pockage.

By Increasing the contact between enzymes and substrate, certain detergents tend to 1 ncrease the rate of oll or asphalt oxidation. good many specles of bacterla produse surfactents (31,32), The microblal production, properties, and functions of surfactants, with particular reference to petroleun, have been reviewed by zajic and Panchal (33). The blodegradation of asphaltenes and other nydrocarbons by a Pgeudomonas species was found (34) to be promoted by blo-emulsifiers or surfactants.

Corynebacte 1 um 1epus and PReudononos asphalten1cus are new species of bacteria recentiy isolated (35) from asphalt deposits in ontar10, canada. Both species attack higher hydrocarbons and produce surfaco-active substances that subatantialy reduce the interfacial tension of mineral salts aolution over layered with kerosene. Although its optimal growth was on n-decane, p. asphartenlcus was shown to utillze a wide range of hydrocarbons, including asphal tenes which make up an apprectable part of nost asphalts. 


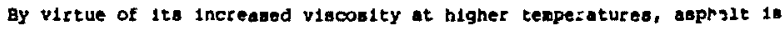
more suaceptible to alcrobial degradetion at increased temperatures. Hicroblat reaction rates are also accelecated by higher temporaturea to the extent that the ayaten is thermostable. However, the highest temperature at Which microbial activity occurs appears to be in the nelghborhood of $100^{\circ} \mathrm{C}$, significantly above the $70^{\circ} \mathrm{C}$ expected in a low-level transuranic wate repository $(6)$.

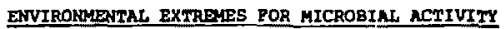

Relatively few microbial sgecies sucvive prolonged exposure at temperatures higher than 55 to $60^{\circ} \mathrm{C}$. However, aeveral specles of thermophilic algae, bacteria, and flingt thrive ac temperatured ranging from 45 to $70^{\circ} \mathrm{C}\{36\}$. A Eew species grow in thermal waters at 70 to $95^{\circ} \mathrm{C}$. Bacteria have been found growing profusely on glags glides abmerged in hot springs at 93.5 to $95.5^{\circ} \mathrm{C}$ (37). sulfate-reducing bacter ia were recovered fram oil-well cores drilled at $2,000=0,000 \mathrm{n}$, where the ambient temperature was 60 to $105^{\circ} \mathrm{C}(38)$. Cuktures mare grom at $70^{\circ} \mathrm{C}$ at 1 atin. one culture grew at $85^{\circ} \mathrm{C}$ when compreased to 400 atm. At a preasure of 1,000 atw, it reproduced at $104^{\circ} \mathrm{C}$.

Although the mieroblal degradation of oll 1 g generally more rapid in the range of 25 to $45^{\circ} \mathrm{C}$ than at lower temperatures, crude ofl has been shown to be oxidited at cemperatureg as low as $-1.1^{\circ} \mathrm{C}(39)$. Bacter fal growth in glycerol mediun at $-10^{\circ} \mathrm{C}$ hes also been denonatrated (40).

A good many microbial epecies survive prolonged comprestion to 1,000 atm at around $3^{\circ} \mathrm{C}$ (deep-sea tengerature and presaure). However, only a few specie3, called barophllea, are able to grow under these conditions. Host 
bacteria are physiologically active at hydrostatic presaures ranging fron 100 to 400 atm (41). Hyperbaric oxygen, $\mathrm{CO}_{2}$, and certain other gases are bacteriostatic or bactericidal at pressures of only 5 to $10 \mathrm{~atm}$. Again, this may be of considerable significance in a deep geologio isolation facility, due to rock overburden (lithostatic) confining pressures (150 atrospheres in the WPP).

within the range of 0.1 and $30 \mathrm{mg} / 11$ ter, the concerteration of dissolved oxygen has no discernible effect on the rate of hydrocarbon oxidation by microorganisas (13). However, the rate of such oxidation is appreciabl: slower in the absence of free oxygen than when some oxygen is present. The microbial oxidation of nydrocarhons under strictly anaeroble conditions has been reported by Tauson and Aleshina (11), Novelli and zoBell (42), Traxler and Bernard (43), Ward and Brock (44), and several others. Ward and Brock (44) demonstrated the transfer of ${ }^{14} \mathrm{C}$ from hexadecane to bacterial bicmass and $\mathrm{CO}_{2}$ under anaerobic conditions.

Although radiolytic degradation of water can yield hyorogen plus oxygen, studies on the radiolytic degradation of cellulosic tranguranic contaninated waste materials $(45,46)$ have indicated that oxygen (in air) originally contained in the waste package is depleted in the formation of $\mathrm{CO}$ and $\mathrm{CO}_{2}$. It has not been determi ned whether asphalt is attacked by microorganisms in the absence of free oxygen. If certain anaerobes attack asphalt, they do so at a rate that is much slower than aerobic degradation.

Various kinds of microorganians differ greatly in theis osmotic pressure or salinity requirements. Most grow best in the neighborhood of 3 to 30 atm. organians that thrive at appreciably higher osmot:i pressures characteristic of brines are degcribed as being osrophilic or halophillc. Those that grow in 
saturated galt golutiona are called extrene malophiles. The ogmotic preasure of an aqueous solution baturated with Nacl 1s about 210 atn. Batreme halophlles reproduce and ace otherwiae phyalologically active in concentrated brines (47), the Dead sea (48), solar galts (49), rock Balt deposite (50), and Great salt wake (51). Smith and zoBell (52) demongtrated the growth of several types of bacteria in Great salt Lake, the salt content of which ranges from 300 to $336 \mathrm{~g} / 1 \mathrm{lter}$. Wuch of the extenslve 11 terature on halophllic bacter la has been reviewed by Flannery (53), Bxown (54), and kushner (55). Hicrooganigag grow in natural conditions and in the laboratory at redox potentials ranging from Eh -450 to $+850 \mathrm{mv}(56,57,58)$. The activity of iron-oxidizing bacterta are normally found in on enviranment with an Eh range linited to +60 to $850 \mathrm{my}$ at one exteme; gulfate-reducing bacter lo ore active in the range of bh -450 to +50 uv.

Bacterla that oxidize aulur to sulfate have been shown to do so in medium that is as acloic as ph 0.5 (59). Starkey and wakgmen (60) reported the growth of Acontlum velatum and other fungus that degrades celluzose in medium as acidic as pH 0.1 . Of the 82 species of bacter 1 a liated by Altman and Dittmer (61), $\theta$ are docurented as being able to grow below pH 2.5 or above pH 10.0. Gae111us c1rculang and Rhizobtum lequninoaarun grew at pH 11.0 . Streptococcus faecal1s grew at ph 11.1. All 51 atrains of Agrobactertum radiobncter studied by Hofer (62) were sald to grow well in media at pl values as high as 11.5 .

\section{REVIEA OF LITERRTURE}

Although the exigting literature avallable on the bacterial degradation of asphalts may not be directly applicable for nuclear waste managenent purposes, a review is presented as background mateilal, for potential applicability. 
Pitch of vegetable origin consisting largely of reilin was reported (63) to be oxidized by various soll bacterla. Guch bacterit were shom to be widespraad in nature, beikg found in gacten, forwst, peat, and oll-field soils. The rate of bacterial deccmposition reached $0.4 \mathrm{~g}$ of pitch per $\mathrm{min}^{2}$ $\left\{\mathrm{dm}^{2}=100 \mathrm{~cm}^{2}-15.5 \mathrm{fn}^{2}\right\}$ of wo11 in $2-1 / 2$ months. The ability of bacterla to degrade pltch wa elosely related to thelt ability to oxidize aromatic hydrocaxbong, phenols, and phenonethanes.

After tinding large populatione of abplalt-oxidizing bacteria in boil underlying defective spots in old aphalt-paved highways, it was auggeated (13) that microbial activity maght contribute to the deterioration of such highways. An examination of 38 different aaphalts provided by the Arerican Petroleum Institute revealed that all were susceptible to wicrobial oxidation in the pregence of moisture, minerals, anc flee oxygen. Big differences were observed in the blodegradability of the asphalts. The degradation rates were generally very alow. Judging from the anount of $O_{2}$ consused, asphalt dispersed in medium on the surface of glass was eatrated to be oxidized at: rates ranging from about 5 to $75 \mathrm{~g}$ per $\mathrm{cm}^{2}$ during eight weeks' incubation at $25^{\circ} \mathrm{C}(13)$.

Wicrobial activity was repocced (14) to be responsible for the deterioration of aephalt roadi in Montana. Burgess (14) suggeated the application of more effective underseals aid better road-grading procedures to prevent soll molsture from contacting the asphalt. He also proposed investigating the feasibility of employing chlorinated asphalts to inhibit nicroblal growth.

Similar obgervations were made by Harris et al. (64) who observed the utilization of asphalt by bacteria associated with asphalt-paved highways in 
Kansas. The bacteria included opecles of Eycobucter1um, Flavobactecium, Pseudononas, and y1crococcus. Hark1s (65) isolated nuterous pure cultures of bacterla frem soll at the soll-ayphalt interface of Kansag highways. wost of the cultures grew in mineral salts modiun containing asplalt as the oole source of energy. The asphalt was dispersed on quartz sand by melting it at increaged tenperature, which probably expelled wone of the wore volutile components. Certain physical propertiea of paving asphalto were shown to be altered by microbial activity at ambient tespermtures within a few weeks. bater, bacteria wece iner iminated $(66)$ in the degradation of asphaltic coatings on plpe burled in soil. dany of the asphalt-utilizing bacteria were similar to those found by farris et al. (15) at the sol1-asphalt interface of Rangas highways. Harris (67) noted a otesdy inerease in the microbial pogulation in soll surcounding dephalt coatings on buried gipes and essentially no mterobial growth around coai-tar coatings. Mainly pseudomonads, corynebacteria, and actinosiycetes were involved in the ossticuction of asphalt.

The corrosion of metal pipes and cables coated with asphalt has been attributed $(16)$ to the microbtal deteriocation of the asphalt. an abundance of asphait-degrading bacteria vere found in the soll sutrounding the conduits. When biturinous roofing material was burfed in moist sot1, 1t was found (69) to give rise to large populations of asphalt-oxidizing becter ia. The microbial destruction of the asphalt was caused by oxidizing bacterla. This microblal destl iction was belleved to leave the residual materials nore susceptible to ablogenic oxidation and other kinds of weathering.

An abundance of sophaltwoxidizing bacteria, expecially species of Pseudononas, Chromobacterium, and Bacillus, were generated in soll in which 
Phillipa and Traxler (69) b's-1ed apphalt aninglep. Certain strains, notably P. aeruginosa, which or Igliully could not utt11ze asphalt, acguired the ability to do so after boing cultivated for a few generations in glucose medium containing asphalt. Eneichment cultures degraded from 3 to 25 percent of the apholt within o week when the wapls of culture fladks were costed with a thin film of asphalt by dissolving it in benzene. After introduction of $100 \mathrm{ml}$ of mineral ast medium into each $1500 \mathrm{ml}$ flask and autoclaving at 1210C tr evaporate all of the benzone. a f1lm of agphalt was layered on the sucface of the mediun as well as on the flask sides and bottom. The asphalt was described as being rich in paraffins.

This raises the question of whether only certain fractions of asphalt are attacked by bacteria. From the extenalve literature on the mictobial ut1lization of petzoleum hydrocarbons and related products, it is well established that certain fractions of crude ofl and products refinef therefrom are more readily utilized than other fractions. But under favorable conditions, virtually all kinds of hydrocarbons and most, if not all, heterocycilc and zesinous compounds appear to be susceptible to microblal attack. (See ceviews by Andelman and Suegs (70), Atlas and Bat tha (71), Beerstecher (72), Dagley (73), Davis (74), Floodgate (75), Foster (79), Fuht (77), Gibson (78), Rogoff (79), Treccant $(60)$, and zoBell $(13,81,82$.

Depending on the kinds of bacteria present and various environmental conditione, the paraffin fractions of asphalts seens to be attacked more rapidly than the heterocyclic compounds of asphaltenes. If so, destruction of the paraffins may render the remalning fractions more volnerable to enzymatc and chenical action. The complete disappearance of the last traces of certain asphaltg subjected to bacterial action for several months is evidence enough 
that all componenta are subceptible to microbial degradation. Nore information is needed on which anphalts are leat suleptible to guch degradazion, ond what can be done to anke them even lese vulnerable to nfcrobial attack. Prelfninary wotk thechenic (4) Indicated thit blom asphalte (used for radioactive vaste encepsulation) are leas attacked than distilled asphalts; bituminous coal tar showed the highest comparative resistance to microblal attack.

Reains of four different kinde of asphalte were ahow: by Traxler et al. (17) to be attacked by soli bacterfa. Kycobacter 14n ranae was shown to nodify the theological properties of auphalt within four monthe at 300c. p. ranae and Nocardia coeliacs caused 1.5 -to 6.8-fold Increases in the relative viscosity of different asphales.

\section{SUNGANY}

The chenical and physical propexties of aphalts that influence their blodegradability have been outlined. Many of the copponents of asphalts, such as asphaltenes, resins, and paraffinle, napthenle, and aroustic hydrocarbons ace more regiatant to chemical reagents, such as atrong acids or alkalines, than to microbial enzye systess. Several different methods for denonstrating the microbial degradation of asphalts have also been described. Since 1934, nearly a hundred different kinds of aspholts have been ghown by various investigators to be degraded by bacterla or related nicroorganlsma. Muthough only a few species attack asphalt, such spectes appear to be widely distributed in soll. They are tost abundant in soll or botton sediments that have been in contact with crude oll or apphalt. Asphalt-oxidizing bacteria have been incr fritnated in the deterioration of appalt-paved atreats and 
agphalt cocings on burled pipes or othor sted atructsces. This suggests that under sertain conditions of storage where alcroorganiome, ninerale essential fur their growth, and a little wolature are present, bituinous coutings might be breached by bacteria within a few decades,

The bacterial degradation of asphalt used for radioactive waste encapsulation has in the past receivad almost negligible study. The reaultant effects and consequences of such degradation, perticularly of metal (radionuclide) metabilization and potentlel enhanced cadionuclide migration, could have a fignificant impact on the acceptability of such waste forms for long-term, deep geological isolation and environmental safety. The specific concerns for use of amphalt (and other organic natrix materials) for nuclear waste manageatent have, thrrefore, been-related to the exlating literature on miccobial degradation of asphalta. A laboratory and field sampling program to address these concerno has been recently initiated and was briefly deecribed. 
1. Proceedings on Biturinization of Lor and Medius Level Radioactive Nestes. Seminar organized jointly by the oect Huclear Energy Agency and the Eurochenic Company, Antwerp. Be:91um, hay 18-19, 1976, Isph 92-64-01509-4.

2. Hild, W., W. Kluger, and $H$, Krause. Bituminlzation of radionctive wates at the Nuclear Research Center Karlaruhe, experience fron plant operation and develoment work, KPK-2328, May, 1976.

3. Stewert, J.F. and $R$. Herter. Solld cadwate expezience in Europe using asphale, 75-Pwr-21, paper presented at the ASKL-IEEs Jo1 nt Power Generation canference, portland, Oregon, september, 1975.

4. KS-Information Brief Report Ho. 20. Rediodetive residues, their origin and elmination, Herner and pflelderer Engineers, stuttgast (FRG) 1975.

5. Nolecke, M.A. Waste I solation Pilot Plant, Transuranic wastes Experimental Progran (SANDT7-1300A). Presented at the 1977 winter Meeting of American Nuclea- Society, San Francisco, Noveaber 28,1977. Published in Transactions of ANs, $27 ; 440,1977$.

6. Malecike, M.A. Waste Isolation Pilot Plant, Transuranic Wastes Experinental Chacacterization Progrem: Executive Sumary, SAND78-1356, Noverber, 1978.

7. D. Caldwell, University of New Hexico, perbonal comssunication, May, 1978.

B. Gruse, W.A. and D.R. Stevens. The Chemical Teonnology of Petroleur, MCGraw-Hill Book Co., Inc.., New York (many tef.), 1960.

9. Sachanen, A.N. The Chenical Congtituents of Petroleur, Reinhoid Pub. Corp., New York, 1945.

10. Bange1, C.A. and G.G. Hawley (eds). The Encyclopedia of Chemistry, Van Nostrad Reinhold, New York, 1973.

11. Tauson, V.O. and V.I. Alesnina. Bacterial reduction of gulfates in the presence of hydrocarbons, M1kroblolog1ya 1:229-261 (75 cef.), 1932.

12. Bundeshagen. P. Behavior of asphalt, bitunen, and coal-tap piech toward mieroorganisns, Bautenschutz, 6:141-142, 1935.

13. zoBe11, C.E. Action of microorganigms on hydrocarbons, Bacteriol. Rev., 10; 1-49, (182 ref.). 1946.

14. Burgess, S.F. Action of microorgantsms on petroleum-asphalt fractions, Highway Res. Board Bull., 118;27-48, 1956.

15. Barrfo, J.O. Agphalt utilization by soil microorganisms, Bacteriol. Proc., p. 25, 1956. 
16. Kulman. F.E. Microblal deterioration of bur led pipe and cable continge, Corrotion, 14:213t-222t, 1958 .

17. Traxker, R.W., P.R. Proteau, and R.N. Traxlec. Action of microorganiams on blturinous materials, I. Effect of bacteria on asphalt viscosity, Appl. Hicrobiol., $13: 80^{\circ}$. 41 (8 EeF.), 2965.

18. Jernelov, $A$, and A.I. Martin. Bcologlcal 1mplications of metal metabolism by microorgan1sins. Adv. Appl. Mtcrob101., 29:61-77, 1975.

19. Brierly, J.A. Mtcrobiological considerations of methodology development for risk evaluation of wate disposal facilities, June 16, 1976, 31-page manuscript prepared for Sandia Latoratories.

20. Lankfork, C.E. Bacterlal assimllation of izon. C.R.C. Crit. Rev, Microbiol. 2:273-330, 1973 .

21 Silverman, M.P. and H.L. Ehrlich. Microblal formation and degradation of minerals, Adv. Appl. Microbiol., 6:153-206, 1964.

22. Fried, S, A. Friedian, et al. Argonne National Laboratory Annuaj, Report for FY1976: The M1gration of Pluton 1 im and Americfum in the Lithr sphere, ANL $-76-127$.

23. Mackregor, R. $\lambda$. Recovery of $v_{3} \mathrm{O}_{\mathrm{B}}$ by underground leaching, Can. Hining Met. Bu11., 59, 583-587, 1966.

24. Zajic, J.E. Uraniun biogeochenistry, p. 197, Microbial Blogeochemistry, Academic Press, 1969.

25. Hirgch, P. 1974. Budding becter 1a, Ann. Rev. Microbiol, (292 ref.) $\underline{25}: 391-444$.

26. Caldwel1, D.E. The planktonic microflora of lakes, C.R.C. Crit. Rev. Microbiol. (583 ref.) $\underline{5}: 305-370,1976$.

27. D. Petersen, Los Alamos Sclentific Laboratory, personal communication, May. 1978.

2B. Holecke, M.A. Sandia Laboratories, Letter to distribution, October B, 1976, Revised representative brines/solutions for wIPP experimentation.

29. Crowe, J.H. and T.S. Clegg (ed.) Anhydrobiosis, Dowden, Hutchinson Rose, Ine.. Stroul .burg, Pa. (many ref.), 1973.

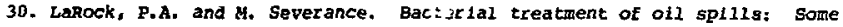
facts considered, P. 309-328. In L. F. Stevenson and R. R. Colwell (ed.), Estuar ine Microbial Ecology, Univ. S. Carolina Press, 1973.

31. LaR1viere, J.h.H. The production of surface active rompounds by microorganigng and its possible significance in oll recovery. I. Some general abservations on the change of surface tension in micrcbial cultures, Antonie van Leeuwenhoek, 2l:1-8 (17 ref.), 1955. 
32. Jones, G.E. and R.L. Starkey. Surface-active eubstanced produced by Thiobacilius thiooxidans, J. Bacter 101, B2:788-789, 1961.

33. zajlC, J.E., and C.J. Panchal. Blo-eauletelers. CRC Crit. Rev. Hicroblol. 5,39-66, 1976.

34. 2aj1C. J.E., D.F. Gerbon, and s.E. Cenp. Blodegradation of anphaltene: and other hydrocacbons by Peudcoonal, Can. Fed. B10l. Soc. 20:33-43, 1977.

35. Gers, 9, D.F., and J.E. Zaj1C. Burfactant production Erom hydrocarbons by Corynes cter lum lepus, ap. nov, and preudomonar auphaltenicue, ap. nov. Dev. Ind. Éscroblol. 19:577-599, 1977.

36. Rose, A.H. (ed.). Thermoblalogy, Acadenlc Preas, New York (ca. 2000 ref.), 1967 .

37. Brock, T.D. Life at high temperatures, Science 158:1012-1019 (70 ref.). 1967.

38. Zoljell, C.E. Ecology of sulfate reducing bacteria, Producers Monthly, 22: $12-29$ (153 ref), 1958 ,

39. ZoBell, C.B. Microbial degradation of o1I: Present Btatus, problems, and perspectives, p. 3-16, In A.G. Ahearn and S.P. Hayers (ed.), The nicrobial degradation of oll pollutants, Center for wetland Resources, Loulgiana State University, Baton Rouge, La., 1973.

40. Lark1n, J.K. and J.L. Stokes, Growth of psychrophille microorganigms at subzero temperatures, Can. J. Microblol, 14:97-101 (16 ref.), 1968 .

41. zoBell, C.E. and E.H. Johnson. The influence of hydrostatle pressure on the growth and viability of terregtrial and marine bacter $1 a, J$. Bacteriol., 57:179-189 (29 ref.), 1949.

42. Hovellf, G.D. and C.E. ZoBell. Assimilation of petroleum hydrocacbons by sulfate-reducing bacter $1 \mathrm{a}, J$. Bacter $101 ., 47$ 447-448, 1944.

43. Traviei. R.W. and J.M. Bernard. The utilization of n-alkanes by Pseudomonas Aeruginosa under conditions of anaeroblosis, I. Preliminary observation, Int. Blodeth. Bull.. 5:21-25 (5 ref.), 1969.

44. Ward, D.M. and T.D. Brock. Anaecobic metabolisin of hexsdecane in sediments, Geomicroblol. J., 1:1-10, 1978 .

45. Transuranlc solid waste management prograns, progress report for July-December, 1975, Los alamos Scientiflc Iaboratory, IA-6481-PR, September 1976.

47. Baas Becking, L.G.M. On organismg living in concentrated brine, Tifa. Ned. Dierk. Ver.. 1:6-9, 1928 . 
18. Elazuri-Volcani, $H$. Bacteria in the botton endinente of the Dead Sea, Naturo, $152: 274-275$ (4 ret.), 1963.

49. Venkatarwen, R. And A. Sreenivaen. Further atudies on the red halophilic buctezia tram solar alt and aslted Einh, Proc. Indan Acad. Sat., 43B:197-206 (14 ref.), 1956.

50. Bien, E. and w. Schwartz. Beonikroblologische Untersuchungen VI. Uber das Vorkomen xonservierter toter and lebender Bakterienzelien in Salgesteimen, 2. Allg. Microbiol., 5:195-205. (Living bacterla detected in rock salt deposite and alwo in solt lakes.) (39 references), 1965.

51. Post, F.J. The micrabial ecology of the Great salt Lake, Microblal Ecol., $\underline{3}: 243-165$ (to ref.), 197 .

52. Snlth, w.W. and C.E. ZoBel1. DIrect microscople evidence of an autochthonous bactexial flora in Great Salt Lake. Ecol., 18:453-458 (12 $r \in f.), 1937$.

53. Flannery, w.t. Curcent status of knowledge of halophilic bacteria, Bacteriol. Rev., 20:49-66 (153 ref.), 1956.

54. Brown, A.D. Aspects of bacterial response to the sontc environment. Bacter 10l. Rev., 28:296-329 (148 ref.), 1964 .

55. Kughner, D.J, HaLophilic bacteria, Adv. Appl. Microbiol., 20:73-99, 1968.

56. Baas Becking, L.G.M., I.R. Raplan, and D. Koore. Limits of the natural environment in terns of pH and oxidation-reduction potentials, J. Geo., 68:243-284 (97 ref.), 1960.

57. Pearsall, w.H. and C.H. Hortimer. Oxidation-reduction potentials in water-logged soils, natural waters and muds, J. Eco1., 27:483-501 (14 ref.), 1939 .

5B、 zoBell, C.E. Studieg on redox potential of marine gediments, Bull. Amer. Assoc, Petrol. Geol, 30:477-513 (76 ref.), 1946.

59. Starkey. R.L. Concerning the physiology of Thlobacillus thiooxidans, an autotrophlc bacter 1 um oxidizj.ng sulfur under acid conditions, J. Bacteriol.. 10:135-163, 1925.

60. Starkey, R.L. and S.A. waksman. Fungi tolerant to extreme acidity and high concentration of copper sulfate. J. Bacteriol., 15:509-519 (14 ref.), 1943.

61. Altman, P.t. and D.S. Dituner. Environnental biology, Fed. Aner. Soc. Expec, Biol., Hashington, D.C. (numerous ref.), 1966.

62. Hofer, A.W. A chatacterization of Bactertum radiobacter, 3. Bateriol., \$1:193-224 (64 ref.), 1941 . 
63. Tauson, V.O. and T.A. Tayes. On the bacterlology of vegutable pitch oxidation, Mlaroblolog1ya, 3,370-381 (25 ref.), 1934.

64. Harris, J.O., A.M. Kline, and C.E. Crumpton. A atudy of the preaence of hydrocarbon-ut12121ng bacter 1 at the sol1-asphalt interface of Kansad highways, Trane. Kaneas hcad. Bc1., 59,495-199, 1956.

65. Hacr1a, J.O. Preliminary atudien on the effect of miecoorganlans on physical propertied of asphalt, Trank. Esnsas Acad. Sc1., 61:110-113 16 (ef.), 1958.

66. Harr18, J.0, Soll microorganiane in relation to cathodicslly protected pipe, Corrobion, 16:441t-446t (2 ref.), 1964.

67. Harria, J.O, gacterial-envi ronmental interactione in corrosion of pipelines, Ecological analysie, Corrogion, 20:335t-340t, 1964,

68. Martin, K.G. Deter loratiol: of bituminous cooftng fabe 1C8, C.S.T.R.O. Div. Bldg. Res., Tech. Eapers, 1,:1-15, 1961.

69. Phill1ps, U.A. and R.h. Trexler. Microbial degradation of asphalt, Appl. Microbiol., 11:235-238 (6 ref.), 1963.

70. Andelmen, J.B. and M.J. Suess. Polynuclear aronatic hydrocarbons in the water environment, Bull. World Bealth Org., 43:479-50e (251 ref.), 1970 .

71. Atlas, R.M. and R. Bartha. Fate and effects of polluting petroleurn in the marine envixonnent, Residue Rev, 49:49-85 (138 ref.), 2973.

72. Beerstecher, E. Detroleun Microblology, Elgevier Presg, New York, (many ref.), 1954 .

73. Dagley, s. Catabollsm and aromatic compounda by microorganiang, hdv. Microbial Physiol., 6:1-46 (150 ref.), 1971.

74. Davis, J.N. Petroleun Microblology, glsevier Pub. Co., Assterdan (866 ref.), 1967.

75. Floodgate, G.D. Biodegradation of hydrocarbons in the sea, p. 153-171. In R. Mtchell (ed.), water pollution microblology, wiley-Interbcience, New york $(92$ ref.), 1972.

76. Foster, J.H. Hydrocarbons as substrates for nicroorganisms, Antonie van Leeuwenhoek, 28:241-274 (69 ref.), 1962 .

77. Fuhs, G.w. Der mikorblelle Abbau von Roblenwasserstoffen. Arch. Mikroblol.. Abt. II, 39:374-422 1271 ref, on microblal decomposition of hydrocarbons), 1961.

78. Gibson, D.T. The mierobial oxidation of arcmatic nydrocarbong, CRC Critical Reviews in Microbiology, p. 199-223 (many ref.), 1971. 
79. Rogofe, M.H. Oxidation of aromatic compounds by bacteria. Adv. Appl. Hicrobiol. 3:193-221 (many cef.), 1961.

80. Treccan1, P. Microbial degradution of nyerocarboni, progrems in Indust. Microblel., $123-33(241 \mathrm{x} \in \mathrm{t}), 1962$.

81. zoBel1, C.E. Anstatiation of hydrocarbons by nicroorganledas AdV. Enzymol., 10:443-486 (236 ceE.). 1950.

B2. 2oBell, C.E. Bacterial degradation of aineral olle at low temperatures, p.153-161. In: A.G. Ahearn and 8.P. Neyers (ed.), The microblal degradation of ofl pollutants, Center for Wetland Resources, Loulsians State Univeralty, Baton Rouge, La., 1973. 
Colin A. Heath, Acting Director

U. S. Department of Energy

DLuigion of ware Isolation

Mo11 Stop B-107

washington, D.C. 20545

Ralph Stein

U. S. Department of Energy

Leader, wIPP project

Office of Nuclear Waste Management

Washington, D.C. 20545

Raymond Ng

D. S. Department of Energy

HIPP Project office

Office of Nuclear maste Manageront

Washington, D.C. 20545

D. T. Schueler, Jr.

0. S. Department of Energy

Albuquerque Operations office

WIPP Project office

P. O. Box 5400

Albuquerque, Hew Mexico 87115

Robert $\mathbf{Y}$. Lawrey

U. S. Department of Energy

Albuquerque operations office

Waste Management Branch

Weapon Production D1vision

P. O. Box 5400

Albuquerque, New Maxico 87215

Office of Nuclear Waste Management

Battelle Project Managument Division s05 king Avenue

Coluabus, Oh1o 43201

Attn: J. M. Batch (5)

A. A. Bauer (1)

Vincent F. Likar

Westinghouse Electr ic Corporation Waste Isolation pliot plant project Advanced Energy Sytems Divlsion p. D. Box 40039

Albuquerque, New Nexico 87916

Dr. Bruno Giletti, Co-chairman

Department of Geological sciences

Brown University

Providence, Rhode Is Iand
Dr, Raymond stever, Co-chatrman Department of Geológical Bciences Harvard Un Lveralty

Carblige. Haseachusetts

Dr. John Hand $\mathrm{n}$, D 1 rector

Center for Tectonophysica

Texas $A$ - M Untveralty

college station, Texas

Dr. John Lyone

Department of Eerth Sctences

Dartmouth college

Hanover, New Hampohlze

Dr. Gearge Pinder

Department of Cluil Engineering

Princeton Unlversity

Princeton, New Jergey

J. B. Stewart

Herner and pflelderer Corp.

160 Hopper Avenue

Waldwick. New Jergey 07463

Brookhaven National Laboratory

Department of Applied sclences

Upton, New York 11973

Attn: P. Colombo (1)

R. M. Nielson (1)

Argonne National Laboratory

9700 8. Cass Avenue

Argonne, Illinols 60439

Aten: S. Fried (1)

LOB Alamos Scientific Laboratory

Los Alamos, New Kexico a7545

Attn: B. J. Garnhart, B-9 (1)

T. R. Reenan, H-7 (L)

D. F. Petersen, H-DO (1)

G. R. Waterbury, $\mathrm{CMB}-1$ (1)

A. zerwekh, CMB-1 (1)

s. Kosiewicz, $\mathrm{CHB}-1$ (1)

New Mexico Tech

Socorro, New Hexico 87801

Attn: J. A. Brierly, Biology Dept. (1)

University of New Mexico

Albuquerque, New Hexico 87131

attn:. D. E. Caldwel1, Biology Dept. (1) 


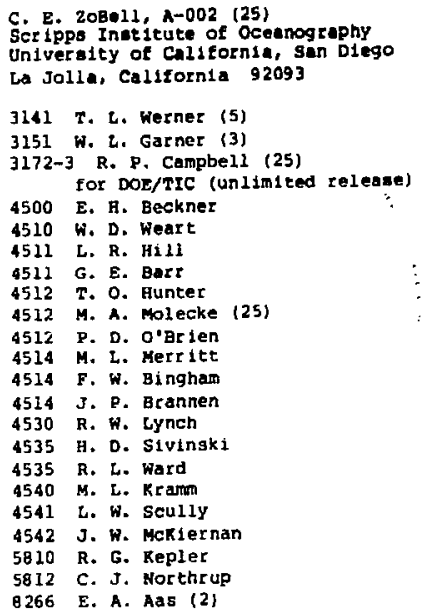

